\title{
The Global Goals: Formalism Foregone, Contested Legality and "Re-imaginings" of International Law
}

\section{Duncan French*}

\begin{abstract}
The Global Goals adopted in 2015 are the next phase in the UN's plans to tackle poverty and the systemic causes of under-development and other global problems. As with the previous Millennium Development Goals, the Global Goals are expressly political in nature. This paper considers the function, status and role of international law in global development and, in particular, how the Global Goals might be perceived in legal terms. The paper rejects the argument that they represent customary law due to weaknesses in State practice and opinio juris, and is unpersuaded that it is helpful to categorise them as soft law as their purpose is aspirational and not regulatory. Thus, the Goals exist in an arena of contested legality. Two "re-imaginings" of international law are proposed; first, by connecting them to the non-binding Maastricht Principles on the Extraterritorial Obligations of States in the Area of Economic, Social and Cultural Rights and secondly, by linking them to ideas of international solidarity. The paper concludes that neither provides easy solutions. Nevertheless, what both do - in their own way - is to force us to question why international law isn't viewed as an acceptable conduit for the advancement of global development?
\end{abstract}

'...development is a mutually beneficial concept. The objective is to raise the tides and lift all boats. International law, with its unique structure and binding language, represents the levies, docks and canal works, channelling the waters and ensuring access and fair play for all involved.'

\section{Introduction}

The United Nations General Assembly adopted the Sustainable Development Goals (SDGs) - more commonly known as the "Global Goals" - in September 2015² to run from 2016-2030, as the successor to the Millennium Development Goals (MDGs), which were to expire at the end of that year. The MDGs had, to some extent, and in some quarters, been a surprising success, certainly when contrasted against the low expectations many had placed in previous attempts by the UN to promote and support global development programmes and opportunities. The hope is that despite their differences - discussed in more detail below - the Global Goals will again resonate with (and within) the international community towards proactive and progressive implementation.

From the perspective of international law, however, the Global Goals - as with the MDGs - remain conceptually and programmatically indeterminate. Eschewing formal legal conceptualisation, the Global Goals remain outside the framework of normative rules and international legal processes. Though embedded and finding expression within the work-plans and strategies of the UN and other global and regional bodies (as well as non-governmental organisations), the Global Goals are not only explicitly political they are, more specifically and overtly, non-legal. While one might make a case to

\footnotetext{
* University of Lincoln, Lincoln, United Kingdom. Email: dfrench@lincoln.ac.uk.

${ }^{1}$ de Serpa Soares (2015), p. 3.

${ }^{2}$ For information on the Global Goals, see http://www.globalgoals.org/.
} 
argue international organisations (especially those within the UN system) are required to act to support the Goals, the commitment of States towards them is much more difficult to categorise.

Whether the Goals might separately be construed as "soft law" is invariably part of the discourse, but that only takes us so far, as soft law often - and I would argue invariably - presupposes some movement of travel towards a level of bindingness, and it is unclear whether that it is even relevant in this context. What this paper therefore seeks to consider are certain broader normative questions; should the Global Goals be re-imagined as international law, what that might look like and how might that be distinct from what exists now? Two putative routes are considered; namely the recently proposed (non-binding) Maastricht Principles on the Extraterritorial Obligations of States in the Area of Economic, Social and Cultural Rights and the ongoing work of the Independent Expert on Human Rights and International Solidarity. Though there are genuine questions as to whether clearer normativity would make objectives such as the Global Goals more, or less, effective - many suspect the latter - there is perhaps a broader, more overarching, question of why shouldn't they be binding? Why isn't international law viewed as an acceptable conduit and process for advancement of global development priorities? Placing the quotation at the beginning into a question, is international law part of the international toolkit to 'raise the tides and lift all boats'?

\section{Development, the MDGs and the Global Goals - False Starts and Winning Formulas?}

The United Nations has international development as one of its core purposes, building on article 1(3) of the Charter, which recognises the Organisation's pivotal role 'in solving international problems of an economic, social, cultural, or humanitarian character'. The Economic and Social Council, in particular, was established within the United Nations to promote and coordinate institutional action and intergovernmental discussion on, inter alia, development. Amongst the bodies and programmes established by States, or through the UN, over the years to consider these issues include the UN Development Programme (UNDP), the World Health Organization (WHO), the Food and Agriculture Organization (FAO), UNICEF (UN Children's Fund), and UNESCO (UN Educational, Scientific and Cultural Organization). Overseeing all of this is the General Assembly. In addition, the Bretton Woods institutions of the World Bank and the International Monetary Fund (IMF) and, somewhat later in development, the World Trade Organization (WTO) - connected to but outside the UN family of institutions - play key, if invariably controversial, roles in both the operational and strategic approach of the global effort towards tackling poverty and underdevelopment. Thus, despite or because of best efforts, institutional fragmentation and strategic in-fighting between institutions has always been a wellrecognised feature of global development policy. ${ }^{3}$

It would prove moot to seek to elaborate on the variety of understandings and definitions of development provided over the years and the extent to which these interpretations say more about the internal politics of the authoring institution than the issue itself. Indeed, such definitions determine the parameters of the debate; perhaps no more evident than when development shifted in the middle 1980s onto new ground to incorporate an environmental dimension within the concept of sustainable development ${ }^{4}$ to then shift further into more holistic understandings of social and human development, and human security. ${ }^{5}$ And though much work has been done on bringing different interpretations together - largely down to the collaborative work around the MDGs - differences in focus and tone remain. So, for instance, whereas the present mission of the World Bank is to 'end extreme poverty within a generation and boost shared prosperity ${ }^{6}$ and that of the UNDP is not dissimilar ('Helping

\footnotetext{
${ }^{3}$ See various contributions in Boas and McNeill (eds) (2003).

${ }^{4}$ World Commission on Environment and Development (1987).

${ }^{5}$ UNDP (1994).

${ }^{6}$ http://www.worldbank.org/en/news/feature/2013/04/17/ending_extreme_poverty_and_promoting_shared_pros perity
} 
countries to achieve the simultaneous eradication of poverty and significant reduction of inequalities and exclusion ${ }^{7}$ ), this is not to ignore the much broader perspective of development endorsed by the General Assembly itself:

Sustainable development recognizes that eradicating poverty in all its forms and dimensions, combating inequality within and among countries, preserving the planet, creating sustained, inclusive and sustainable economic growth and fostering social inclusion are linked to each other and are interdependent. ${ }^{8}$

Such understandings are, of course, far from being irreconcilable or mutually exclusive (and both the World Bank and the UNDP also endorse broader approaches to development to include environmental sustainability and social inclusion), but such differences in wording do nevertheless reveal a broader, and deeper, complexity; how to connect (and embed synergies between) the overarching objectives of poverty reduction and development promotion within particular institutional mandates and actions.

It is thus unsurprising that over the decades, the UN (both as an institution per se and as a forum for its members) has sought various means by which to tackle development, often in quite disparate ways. They have ranged from the adoption of so-called "decades of development" (the term itself suggesting both the long-term endeavour of the mission and the frustration as one decade of development slipped into the next), the concerted (if acrimonious) attempt by the Global South to establish a New International Economic Order (NIEO) ${ }^{10}$ through to now a seeming consensus around headline targets and measurable indicators. Simultaneously, the Bretton Woods institutions have evolved; ${ }^{11}$ moving away from the dogmatic Washington Consensus of the 1980s, which represented a strategy and practice often at odds with the vision of the majority of its own developing country membership of the UN. This is a long, and often-repeated, story of global international development, of the imposition of neoliberalism, tied aid and interference with host States. It has often been a story of international rhetoric yet substantive inactivity (or worse, ineffective activity) on development policy and praxis; of the paradox of emotive words combined with the absence of long-term strategy and consequently positive outcomes. The success that was achieved was often low-level, and the results of macro-projects funded through organizations such as the World Bank seemed hopelessly random, with huge social negative externalities often being as prominent as the benefits of such programmes. ${ }^{12}$

Also absent, from the perspective of the international lawyer, was any form of serious international legal engagement in such matters; the Bretton Woods institutions, for instance, have always sought to place their own activities within tightly-woven (and, as importantly, internal) systems of rules and processes, with as little scrutiny from external review - or general international law - as possible. The quid pro quo offered was that such institutions did not seek to intervene in the internal political affairs of the States in which they operated; the economic rationale of their mandate being a purely technocratic one. Change has come, but it often seems grudging and determined by - and at the pace of - the institutions themselves.

The governance of international trade has equally struggled with balancing the reciprocity of trade commitments with ensuring special and differential treatment for developing countries. The most recent WTO Ministerial Conference in Nairobi in December 2015 revealed a stark realism as to how far long-

\footnotetext{
7http://www.undp.org/content/undp/en/home/librarypage/corporate/Changing with the World_UNDP_Strategi c Plan_2014_17/

${ }^{8}$ UNGA (2015), para. 13.

${ }^{9}$ Various (2011).

${ }^{10}$ Meagher (1979).

${ }^{11}$ Darrow (2003).

12 Wendt (1999), pp. 149-162.
} 
held hopes for the Doha "development" trade round were no longer driving its agenda, ${ }^{13}$ in contrast to the fine words of previous meetings, and even as recently as September of the same year. ${ }^{14}$ Regional and pan-regional trading blocs and preferential trade and investment agreements are becoming the increasingly dominant form of intergovernmental agreement, ${ }^{15}$ raising not only the question as to the raison d'être of the WTO but fundamentally risking the objective of balanced development in trade negotiations.

Similarly, despite decades since the adoption of the Universal Declaration on Human Rights and the 1966 International Covenants on Civil and Political Rights, and Economic, Social and Cultural Rights, human rights law remains stubbornly outside the mainstream of development policy and operational activity. ${ }^{16}$ As the Special Rapporteur on Extreme Poverty and Human Rights, Professor Philip Alston, noted in a damning 2015 report:

For most purposes, the World Bank is a human rights-free zone. In its operational policies, in particular, it treats human rights more like an infectious disease than universal values and obligations. The biggest single obstacle to moving towards an appropriate approach is the anachronistic and inconsistent interpretation of the "political prohibition" contained in its Articles of Agreement. As a result, the Bank is unable to engage meaningfully with the international human rights framework, or to assist its member countries in complying with their own human rights obligations. ${ }^{17}$

This might, of course, be as much the fault of those with responsibility for the advancement of human rights as it is with those with a similar responsibility for development (a point Alston has also had the opportunity to make ${ }^{18}$ ), but nonetheless normative and institutional barriers as to who is responsible for what have proved incredibly difficult to breakdown. The 1986 UN Declaration on the Right to Development ${ }^{19}$ - imperfect as it was - is thus perhaps not so much as anomaly in this area, as a missed opportunity for the General Assembly to take overall strategic responsibility for this issue.

Moreover, international aid ('official development assistance' (ODA)) and the "obligation" to bestow it remains outside the purview of international law. Political commitment to ODA has never found legal expression, though certain States have committed themselves to it within domestic law. ${ }^{20}$ The extent to which solidarity and positive cooperation in the field of development have consistently failed to be the subject of normative explanation is mirrored only by the reality that globalising pressures and private resource often makes such public provision, however essential, of secondary importance.

For the international lawyer, overarching this is a realisation that the role of international law in development has traditionally been limited and nuanced. Not just that, but there is little sense of progression; of the gradual evolution of State practice and opinio juris that constitutes customary rules

\footnotetext{
${ }^{13}$ WTO (2015), para. 30: 'We recognize that many Members reaffirm the Doha Development Agenda, and the Declarations and Decisions adopted at Doha and at the Ministerial Conferences held since then, and reaffirm their full commitment to conclude the DDA on that basis. Other Members do not reaffirm the Doha mandates, as they believe new approaches are necessary to achieve meaningful outcomes in multilateral negotiations...'.

${ }^{14}$ UNGA (2015), para. 68: 'We call upon all members of the World Trade Organization to redouble their efforts to promptly conclude the negotiations on the Doha Development Agenda'.

15 See, for instance, the adopted Trans-Pacific Partnership (TPP) and the ongoing negotiations between the US and the EU for a Transatlantic Trade and Investment Partnership (TTIP).

${ }^{16}$ Nevertheless, see Salomon (2007).

${ }^{17}$ Alston (2015), para. 68.

18 Alston (2005), p. 827.

${ }^{19}$ UNGA (1986).

${ }^{20}$ See, for instance, as regards the UK: International Development (Official Development Assistance Target) Act 2015, section 1(1): 'It is the duty of the Secretary of State to ensure that the target for official development assistance (referred to in this Act as "ODA") to amount to $0.7 \%$ of gross national income (in this Act referred to as "the $0.7 \%$ target") is met by the United Kingdom in the year 2015 and each subsequent calendar year'.
} 
on international development. As noted above, the NIEO was unduly partisan in nature and rejected with suspicion by developed States as one-sided, regardless of the existence or otherwise of any specific merits. Ultimately, it failed under the weight of its own expectations and the lack of political engagement by the United States and the European north. Various attempts have been made to identify and progressively develop legal rules that might frame a broader normative understanding of development - devised often at a non-governmental level ${ }^{21}$ - but such arguments remain at best aspirational and perhaps, more notably, marginalised. The traditional response is that developed States will not provide assistance through compulsion; voluntarism is the best form of self-interest.

It was in this context that the General Assembly adopted the 2000 Millennium Declaration, including what subsequently became the Millennium Development Goals. ${ }^{22}$ The eight MDGs were headline targets that it was hoped the international community of States, multilateral agencies and NGOs would coalesce around. Perhaps most prominently were the targets reducing extreme poverty by half, reducing child mortality of the under-fives by two-thirds and ensuring universal primary education for all. Though not without criticism, ${ }^{23}$ sometimes strident, the MDGs have surpassed the relatively low expectations many had for them. In part, this was because the MDGs were both strategic yet not unduly prescriptive, two faults previously seen in global development policy. As the UN Secretary General notes in his foreword to the 2015 Millennium Development Goals Report, worth quoting at length:

The global mobilization behind the Millennium Development Goals has produced the most successful anti-poverty movement in history. The landmark commitment entered into by world leaders in the year 2000 - to "spare no effort to free our fellow men, women and children from the abject and dehumanizing conditions of extreme poverty"-was translated into an inspiring framework of eight goals and, then, into wide-ranging practical steps that have enabled people across the world to improve their lives and their future prospects. The MDGs helped to lift more than one billion people out of extreme poverty, to make inroads against hunger, to enable more girls to attend school than ever before and to protect our planet. They generated new and innovative partnerships, galvanized public opinion and showed the immense value of setting ambitious goals. By putting people and their immediate needs at the forefront, the MDGs reshaped decision-making in developed and developing countries alike. ${ }^{24}$

A high degree of rhetoric, and in danger of transcending into hubris, but there is also a not insignificant element of truth. The MDGs have achieved results. As Bill Gates famously said, they were a 'report card that helps us judge our performance'. ${ }^{25}$ It was in this spirit that the international community endorsed in 2012 at the Conference on Sustainable Development (the so-called Rio +20 summit) the beginnings of the work on the next stage. Noticeably, whereas the MDGs had been crafted privately by "experts" within the United Nations, the Sustainable Development Goals (as the Global Goals were initially called) were to be the subject of a two year consultative process, involving both States and nongovernmental organisations. ${ }^{26}$ This process - which, at times, risked becoming subject to the usual global problem of high expectations, and low achievement - emerged into the glare of media and political attention in late summer 2015, just prior to, and then during, the UN summit of world leaders.

Of particular concern had been that the Global Goals would become an unmanageable list of such wideranging, yet worthy, objectives that they would be incapable of either sensible implementation or of meaningful cross-cutting connectivity. To take one example, returned to later, there was a significant

\footnotetext{
${ }^{21}$ ILA (1986), pp. 1-11.

${ }^{22}$ UNGA (2000).

${ }^{23}$ Amin (2006); see also Alston (2005), pp. 762-768.

${ }^{24}$ http://www.un.org/millenniumgoals/2015_MDG_Report/pdf/MDG\%202015\%20rev\%20\%28July\%201\%29.p df.

${ }^{25}$ http://www.gatesfoundation.org/media-center/speeches/2008/09/bill-gates-speaks-at-the-united-nations

${ }^{26}$ This paper develops on some earlier thoughts on the adoption of the Global Goals, contained in French (2015), pp.77-79.
} 
push by a broad group of organisations and agencies to include culture within the Global Goals, it being noted that the MDGs were noticeably absent in this regard. In and of itself, how could this be objected to? As the Declaration for the Inclusion of Culture states, 'We believe that culture is both a driver and enabler of sustainable development and that the explicit inclusion of targets and indicators for culture in the Sustainable Development Goals will enable transformative change'. ${ }^{27}$ Surely it would not be wrong to recognise both the generic role of culture in this regard or, indeed, the contributions that different cultures make, thus ensuring critical engagement with different societies, groups and the under-represented in the Goals? Others worried that the simplicity and effectiveness of referencing only headline targets would be lost by seeking to be all-inclusive, of incorporating all interests and many agendas. Such examples of what to include (and to omit) were myriad and cross-cutting, but they often had one thing in common; a fear (real or imaginary) of what exclusion would mean. To return to the above declaration: 'If culture is not mentioned, it will be extremely difficult for countries to elaborate policies and provide funds for projects that rely on culture's role as a driver and an enabler of sustainable development'.

\section{Global Goals: What's Lost in All that is Included?}

Ultimately what transpired in Transforming our World: the 2030 Agenda for Sustainable Development ${ }^{28}$ the 'outcome document' of the summit - interesting language itself for an organisation that often likes to see things in terms of declarations - is a balance between what was wanted and what many feared. The Global Goals comprise 17 goals, 169 associated targets and more than 300 indicators of progress. Whether it was the scale of the global ambition required to achieve such various objectives or the spread that such objectives cover that justified the change in name from Sustainable Development Goals to Global Goals is not clear, though their remit is invariably more expansive than the MDGs. As the Outcome Document reflects:

[t]his is an Agenda of unprecedented scope and significance. It is accepted by all countries and is applicable to all, taking into account different national realities, capacities and levels of development and respecting national policies and priorities. These are universal goals and targets which involve the entire world, developed and developing countries alike. ${ }^{29}$

Moreover, the Global Goals selected range significantly beyond the development priorities of the past - reducing poverty, mortality, hunger etc - but expressly sought to tackle a broader panoply of issues; arguably to include much more systematically the underlying and systemic causes of unsustainable development, as broadly conceived. Perhaps more noticeably still - and as indicated by the above quotation - is the reach of the Global Goals. Whereas the MDGs were primarily objectives of the international community for the global South, the Global Goals are objectives both of, and for, the international community more generally. As has been noted, if with some over-generalisation: 'Poorer countries need to make the delivery of basic services such as health and education to all their citizens the priorities; emerging economies need to ensure safety and protect human rights; richer countries need to face up to the problems of affluence, such as obesity, and work on building tolerant societies; everyone has a long way to go on environmental sustainability'. ${ }^{30}$

It might be useful at this point to list the 17 Global Goals: 1) to end poverty in all its forms everywhere; 2) to end hunger, achieve food security and improved nutrition and promote sustainable agriculture; 3 ) to ensure healthy lives and promote well-being for all at all ages; 4) to ensure inclusive and equitable quality education and promote lifelong learning opportunities for all; 5) to achieve gender equality and

\footnotetext{
${ }^{27} \mathrm{http}: / / \mathrm{www}$. culture2015goal.net/.

${ }^{28}$ UNGA (2015).

${ }^{29}$ UNGA (2015), para. 5.

${ }^{30}$ Green (2015).
} 
empower all women and girls; 6) to ensure availability and sustainable management of water and sanitation for all; 7) to ensure access to affordable, reliable, sustainable and modern energy for all; 8) to promote sustained, inclusive and sustainable economic growth, full and productive employment and decent work for all; 9) to build resilient infrastructure, promote inclusive and sustainable industrialization and foster innovation; 10) to reduce inequality within and among countries; 11) to make cities and human settlements inclusive, safe, resilient and sustainable; 12) to ensure sustainable consumption and production patterns; 13) to take urgent action to combat climate change and its impacts; 14) to conserve and sustainably use the oceans, seas and marine resources for sustainable development; 15) to protect, restore and promote sustainable use of terrestrial ecosystems, sustainably manage forests, combat desertification, and halt and reverse land degradation and halt biodiversity loss; 16) to promote peaceful and inclusive societies for sustainable development, provide access to justice for all and build effective, accountable and inclusive institutions at all levels; and 17) to strengthen the means of implementation and revitalize the global partnership for sustainable development.

By anyone's reckoning, this is a significant list of goals. Whether they are sufficiently coherent and memorable to capture - and retain - global attention only time will tell. For critics, it is a shopping-list of idealism that reveals a chasm of political realism in the workings of the United Nations; a utopian view of what international bureaucracy can achieve. ${ }^{31}$ For others, their principal fault will lie with not being ambitious enough. There are fault-lines everywhere; too much or too little State intervention required; too much or too little focus on private investment; and too much or too little attempt to connect the various thematic issues. And so one might go on.

Unlike the MDGs, there are some notable additions, recognising not only the clearer environmental foci of some of the goals (eg Goals 13-15) but also the more societally-transformative nature of some of the others (eg Goals 4, 5, 10 and 11). Moreover, unlike the MDGs, which were largely macro-targets achievable as much through national economic growth as national policy-making, many of the Global Goals will not be so easily reconciled with, or achieved through, a growth-alone approach to development. Targets around gender equality, biodiversity loss and access to justice (to name but three) will require clear, principled and overt strategic intervention and coordinated policies and partnerships. Growth alone with not solve these social issues; in fact, growth without well-considered public policies might make them more difficult to progress.

Nevertheless, a significant issue around all of the Goals is the scale of financial commitment required to ensure their effective implementation. Most assessments have indicated a commitment of several trillion US dollars per annum across domestic, international and private resources to turn the Goals into reality. The 2015 Addis Ababa Action Agenda for Financing for Development, ${ }^{32}$ adopted before the Goals themselves, set out a plan (of sorts) to begin mobilising such resource though compromises and disagreements abounded on international tax reform, the clamping down on illicit financial flows and ensuring more equitable distribution of official (never mind private) investment within the global South. This document, like many before it, is replete with many of the right words but, in truth, resource (and action) rarely follows to the same extent.

It is perhaps pertinent here to pause and note the role (and absence) of law in not only achieving the Goals per se (something which is returned to) but also around the achievement of financing to support it. The Addis Ababa Action Agenda envisages law, to the extent that it is mentioned at all, as something akin to background fact, as an immovable framework that future programmes and initiatives must work within, as providing "rules of the game" but where the game itself remains unquestioned. Often it seems that there is little recognition that international law is created by the very States that are also negotiating how to resolve contemporary global challenges. Rarely are global rules considered enabling or

\footnotetext{
${ }^{31}$ Hickel (2015): 'The SDGs fail us on this. They offer to tinker with the global economic system in a wellmeaning bid to make it all seem a bit less violent. But this is not a time for tinkering'.

${ }^{32} \mathrm{UN}(2015)$.
} 
sufficiently capable of transformative action to prompt or cause fundamental reform. ${ }^{33}$ Law is thus both supremely important, yet contemporaneously viewed as marginal in relevance to global development. ${ }^{34}$

Two examples perhaps suffice. On the taxation of multinationals, for instance, the ability to change (or even strengthen) the law is hardly acknowledged; rather, law is seen as a restraint on the regulatory behaviour of any one State, so that it conducts its affairs 'in accordance with national and international laws and policies' ${ }^{35}$ No reference here to the weaknesses in, or limitations of, the present state of the law. The contested and evolving nature of international agreements gives way to a fixed sense of normativity, in which the fundamental precepts are removed from, and not part of, the discourse.

Secondly, as regards sovereign debt - a hugely controversial issue - the wording of the document is even more instructive.

...We encourage countries, particularly those issuing bonds under foreign law, to take further actions to include [collective action] clauses in all their bond issuance. We also welcome provision of financial support for legal assistance to least developed countries and commit to boosting international support for advisory legal services. We will explore enhanced international monitoring of litigation by creditors after debt restructuring.

We note the increased issuance of sovereign bonds in domestic currency under national laws, and the possibility of countries voluntarily strengthening domestic legislation to reflect guiding principles for effective, timely, orderly and fair resolution of sovereign debt crises. ${ }^{36}$

It is beyond the scope of this paper to consider these issues in anything like the detail they require and deserve. ${ }^{37}$ Merely to note at this stage the passive role given to (domestic public) law (as well as the non-existence of international law); certainly in contrast to the primacy given to the assurance of contractual undertakings. To the extent that predatory behaviour of creditors is perceived as a problem, the extent of action is an exploration of future monitoring of litigation practices and patterns. The protection bestowed upon least developed countries is singularly apparent; it is restricted to legal assistance and advice. This is, of course, not to suggest that such initiatives are not constructive and helpful but rather the point is more generic; law as a tool of change is rarely part of the equation. Law is a given, a constraint or, where change is mooted, voluntary and soft. To change the structure, the law - the "rules of the game" themselves - is often viewed as a return to the partisan, and divisive, days of the New International Economic Order. Nevertheless, as Salomon pertinently notes,

It would seem we need to turn our attention from the poor to the rich, from the victims to the beneficiaries, because it is only by addressing the apparatuses that sustain world privilege that we can understand and hope to confront the mechanisms that maintain world poverty. The adoption and enforcement of legal regimes have, and will continue to play, a critical role in this process. ${ }^{38}$

\footnotetext{
${ }^{33}$ Moreover, as the former on UN Special Representative on Human Rights and Business Enterprises notes, traditional international legal norms are inapplicable directly to private enterprises (Ruggie (2006), para. 64: 'None of these changes, however, support the claim on which the Norms rest: that international law has transformed to the point where it can be said that the broad array of international human rights attach direct legal obligations to corporations, a claim that has generated the most doubt and contestation'). Of course, the Norms referred to were the controversial Draft Norms on the Responsibilities of Transnational Corporations and Other Business Enterprises with Regard to Human Rights (2003).

${ }^{34}$ This should not however ignore the role of private law in development (see, for instance, Rühmkorf (2015)).

${ }^{35} \mathrm{UN}(2015)$, para. 23.

${ }^{36} \mathrm{UN}$ (2015), paras. 100-101.

${ }^{37} \mathrm{IMF}(2014)$.

${ }^{38}$ Salomon (2008), pp. 72-73.
} 
To thus return to the Global Goals themselves; the absence of law (broadly conceived) is not accidental, but is a clear and explicit attempt to de-legalise the targets.

The next part of this paper will consider some of the consequences that flow from this, and seek to reimagine alternative scenarios. But it is important to note the chasm between the rhetoric and some very obvious omissions, most notably around human rights. As has been widely remarked upon, despite the increasing attempt to couple business, development and human rights in recent years, ${ }^{39}$ the Global Goals are reflective of the MDGs in overtly failing to utilise human rights, and human rights language, in the text of their wording. Notwithstanding the universalism of human rights, the Global Goals are singularly shorn of their human rights implications, beyond the barest of references. ${ }^{40}$ Putting to one side for the moment the myriad of interconnections between the Goals and economic, social and cultural rights (and indeed certain civil and political rights ${ }^{41}$ ), even as regards those Goals where it would seem almost impossible not to place the relevant Goal within its associated human rights framework, there is nothing.

Take, for instance, gender equality; much was made of how the Global Goals were a fundamental jumpforward in development policy (vis-à-vis the MDGs) on gender issues. ${ }^{42}$ Despite this, there are no express references to human rights generally or, more specifically, the 1979 Convention on the Elimination of all Forms of Discrimination against Women. Similarly, despite the advances in recent years, references to non-discrimination still exclude LGBT considerations, ${ }^{43}$ primarily at the insistence of various religiously-conservative States. Thus, to this extent, the Global Goals are a product and a representation of a conflicted international community as it both seeks to portray itself and, in reality, how it is.

It is thus both surprising (and simultaneously not surprising) to hear the UN Secretary General at the Human Rights Council in 2016 to say ' $[\mathrm{t}$ ] $\mathrm{he} 2030$ Agenda for Sustainable Development is a major step forward for human rights... The integrated, indivisible and universal nature of the 17 Sustainable Development Goals is deeply rooted in universal human rights' ${ }^{44}$ In a quixotic sense, the Global Goals are a manifestation of where human dignity leads, and what it obliges. But equally, as Alston noted so forcibly as regards the MDGs, 'language as well as context is important. The language of human rights cannot be systematically ignored if claims of human rights friendliness are to be accepted at face value'. ${ }^{45}$ A similar argument could be made as regards the Global Goals; indeed, the international community does not seem to have moved on in the over fifteen years since the inception of the MDGs.

\section{The Global Goals and/as international law: hard, soft or re-imagined?}

Transforming Our World is a paradoxical document when it comes to international law. On the one hand, it makes mention of - and with suitable deference to - international law.

We will implement the Agenda for the full benefit of all, for today's generation and for future generations. In doing so, we reaffirm our commitment to international law and emphasize that

\footnotetext{
${ }^{39} \mathrm{UN}(2011)$.

${ }^{40}$ UNGA (2015), para. 19: 'We reaffirm the importance of the Universal Declaration of Human Rights, as well as other international instruments relating to human rights and international law. We emphasize the responsibilities of all States, in conformity with the Charter of the United Nations, to respect, protect and promote human rights and fundamental freedoms for all...'.

${ }^{41}$ For instance, Global Goal 16: Peace, Justice and Strong Institutions, which includes targets on violence and violence-related deaths, trafficking and torture of children, guaranteeing birth registration, and access to justice.

42 Vogelstein (2015).

${ }^{43}$ http://www.stonewall.org.uk/sites/default/files/sdg-guide_2.pdf

44 http://www.un.org/apps/news/infocus/sgspeeches/statments_full.asp?statID=2946\#.VzWxck10zIU

45 Alston (2005), p. 826.
} 
the Agenda is to be implemented in a manner that is consistent with the rights and obligations of States under international law. ${ }^{46}$

This is one amongst a number of statements 'reaffirm[ing]', or highlighting that the Goals are 'guided by' or 'grounded in', international law or, more occasionally, certain named legal instruments. ${ }^{47}$ But, as was noted above, a reference such as 'in a manner that is consistent with' both constrains as well as enables. It frames the available policy space without challenging the underlying structures. It is a phrase often used to deny or to discourage unilateralism, be that progressive or regressive in nature. It both provides continuity and assurance and, however implicitly, often a promise; a promise not to disturb the status quo. Development, if it is to occur, does so through a set pattern; characterised more often than not by aspirational yet self-interested voluntarism of the North, soft nudging of private enterprise and for the global South to follow certain demarcated policy pathways.

It is thus not surprising that the Global Goals are inherently political in nature; in the words of the document they are 'aspirational and global', thus it is left to each individual country to 'set[...] its own national targets guided by the global level of ambition but taking into account national circumstances'. ${ }^{48}$ If there were any emerging view that the MDGs (limited as they were in number) were reflective of putative customary law (and even as far back as 2005, Alston was prepared to go so far as to say that 'it can be observed that the case would be most easily made in relation to the first six of the Goals ${ }^{49}$ ) it is difficult how the same could be said of the more numerous, and perhaps more disparate, Global Goals. Indeed, one of the criticisms of (some of) the goals is that they have lost much of the descriptive-cummoral appeal in their attempt to be more inclusive.

How might one, for instance, understand, communicate, as well as reconcile, the various elements of Global Goal 9 ("To build resilient infrastructure, promote inclusive and sustainable industrialization and foster innovation")? The International Court of Justice in the North Sea Continental Shelf Cases noted that for something to be a rule of custom, it had to be of a 'fundamentally norm-creating character' ${ }^{50}$ While one might debate the extent of the State practice and opinio juris surrounding many of the MDGs, there was often at least a clarity of aim and purpose. It is less simply stated in respect of many of the Global Goals. To take Global Goal 9; what makes infrastructure 'resilient' or industrialization 'inclusive and sustainable'?

And as regards those goals where the language would seem to at least allow for the possibility of greater normativity, at least at the "headline" level (eg Global Goals 14 and 15 on the conservation of maritime and terrestrial ecosystems), it would seem to be just that; a possibility. The Global Goals neither add to, nor detract, from broader debates on the customary status of environmental norms. Their inclusion as Global Goals may signal political importance in tackling the issues - heralded now not only as significant in and of themselves but as causes of poverty and underdevelopment - but the overt lack of legal commitment contained therein means they are a long way removed from indicating any extension of pre-existing normative obligations.

Some might point to the Goals to suggest a form of soft law being in evidence. For sure, not binding; but not completely optional either. If soft law as a workable concept is viewed as a means of incorporating objectives for States to work towards (and concurrently voluntary constraints upon discretionary State conduct) in a similar manner to, but distinct from, binding law, ${ }^{51}$ do not the Global Goals have a similar effect? If one were to consider the monitoring and review mechanisms that

\footnotetext{
${ }^{46}$ UNGA (2015), para. 18.

${ }^{47}$ Instruments mentioned include the 1982 UN Convention on the Law of the Sea and the 2003 World Health Organization Framework Convention on Tobacco Control.

${ }^{48}$ UNGA (2015), para. 55.

49 Alston (2005), p. 774.

${ }^{50}$ ICJ, North Sea Continental Shelf Cases (1969) ICJ Rep 42.

${ }^{51}$ Boyle and Chinkin (2007), pp. 211-229.
} 
developed around the MDGs, ${ }^{52}$ with not dissimilar (with some hope stronger) processes to be established for the Global Goals, might not one see resonance with other soft law commitments? The level of accountability may fall short of that established by some international instruments - be that the reporting requirements under human rights law, the inspection/monitoring processes under such diverse regimes as anti-nuclear proliferation and certain environmental regimes, or the capacity of investorstate resolution under bilateral investment treaties (to name but three "types") - but soft law accountability by its very nature is often achieved as much through (the threat of) collective pressure as it is by formal scrutiny. Thus, when Transforming Our World talks of a 'robust, voluntary, effective, participatory, transparent and integrated follow-up and review framework will make a vital contribution to implementation, ${ }^{53}$ - a key part of which will be undertaken by the already established High-Level Political Forum on Sustainable Development (HLPF) ${ }^{54}$ - surely it is not that different to how other soft law processes operate?

But notwithstanding the appearance of soft law, there is a significant stumbling block in the nomenclature of soft law in this instance. Soft law is not simply a non-binding way to achieve targets and to improve accountability, there is also something invariably iterative and transitional about soft law; it often requires a sense of movement towards, or at a least a contribution to, formal legality. As Boyle and Chinkin note, '[s]oft law is a multi-faceted concept, whose relationship to treaties, custom and general principles is both subtle and diverse. At its simplest soft law facilitates progressive evolution of international law'. ${ }^{55}$ For instance, the development of soft codes of conduct that can be used as evidence of meeting a State's international obligations in international trade law, or litigating (for or against the use of) soft law principles in international courts and tribunals as nascent principles of customary law, or utilising soft law instruments hoping that confidence will build to garner sufficient state endorsement to move to a legally binding agreement. Soft law may fall outside traditional descriptors of what is legally binding, but there is nevertheless an intention, however implicit, to regulate in the absence of law.

With the Global Goals, any contribution to formal legality, and any intention to regulate, is almost wholly missing. There are two quite contrary reasons for this. First, the rhetoric. The purpose of the Goals is - for want of a better phrase - to achieve the common good; they are neither prescriptive and regulatory (as much of soft law is) nor is there any obvious intention of moving towards such prescription and regulation. The numerous targets and indicators are certainly measurable (and thus there is a semblance of commonality between the Global Goals and soft law types) but the end-purpose is too idealised and idealistic to be captured by limited models of governance and regulation that soft law often acts as a proxy for. As Transforming Our World prosaically states

In its scope, however, the framework we are announcing today goes far beyond the Millennium Development Goals. Alongside continuing development priorities such as poverty eradication, health, education and food security and nutrition, it sets out a wide range of economic, social and environmental objectives. It also promises more peaceful and inclusive societies. ${ }^{56}$

A second argument against soft law sits behind this, and is much more critical in nature. It is recognition that such Goals are not established to challenge the international community, but rather

\footnotetext{
52 For general information see Millennium Development Goals Indicators, http://unstats.un.org/unsd/mdg/Host.aspx?Content=Indicators/About.htm.

${ }^{53}$ UNGA (2015), para. 72.

${ }^{54}$ The modalities for which were set out in UN A/RES/67/290 (2013), notably: 'that the high-level political forum, consistent with its universal intergovernmental character, shall provide political leadership, guidance and recommendations for sustainable development, follow up and review progress in the implementation of sustainable development commitments' (para. 2).

${ }^{55}$ Boyle and Chinkin (2007), p. 229.

${ }^{56}$ UNGA (2015), para. 17.
} 
to make a 'rhetorical commitment' ${ }^{57}$ for change. As Salomon comments as regards the MDGs, but the critique could - until contradicted - be held equally against the Global Goals: '[t]he Goals were not set up to address the structural conditions antagonistic to their achievement and they are now serving to advance the economic interests of wealthy states even under the guise of the humanitarianism of addressing world poverty'. ${ }^{58}$ In short, the Goals are neither soft nor binding law not only because of the aspiration of their idealism but because of the politics of their construction and implementation. In short, to the extent that soft law merely foreshadows binding law, its application to the Global Goals is equally problematic.

But if the Global Goals were to be viewed, and were to be constructed, as legal norms, how might things look different? It is important to recognise that despite the mainstream rejection of legality, there is nevertheless a strongly held viewpoint prepared to acknowledge wider normative obligations on States in this area. This is achieved primarily by recognising, and giving meaningful effect, to the wording of such texts as the International Covenant on Economic, Social and Cultural Rights, article 2(1) of which requires all States Parties 'to take steps, individually and through international assistance and cooperation, especially economic and technical, to the maximum of its available resources, with a view to achieving progressively the full realization of the rights recognized in the present Covenant by all appropriate means, including particularly the adoption of legislative measures'. This received further elaboration by the Committee on Economic, Social and Cultural Right's in which it was said

The Committee wishes to emphasize that in accordance with Articles 55 and 56 of the Charter of the United Nations, with well-established principles of international law, and with the provisions of the Covenant itself, international cooperation for development and thus for the realization of economic, social and cultural rights is an obligation of all States. It is particularly incumbent upon those States which are in a position to assist others in this regard. ${ }^{59}$

Alston talked similarly in the midst of the MDGs of the emergence of an 'internationalization of responsibility' ${ }^{60}$ Nevertheless, whilst acknowledging the MDGs had the potential to change the tone of the debate, he was circumspect as to the likelihood, recognising that there is little practice, never mind consensus, to support the 'proposition that any given country is obligated to provide specific assistance to any other country' ${ }^{61}$ Of particular importance in this regard, but in equal measure controversial, was MDG 8, which required the elaboration of a global partnership for development. But again, the extent to which any such partnership between States and presumably other international actors could evolve from the cooperative to a level of compulsion is deeply problematic when viewed from both what States have said, and how they have historically agreed to work, on development.

Thus, we remain in the area of contested and putative legality. As de Serpa Soares notes, 'a major opportunity also exists for international law to engage at the conceptual heart of the matter'. ${ }^{62}$ Though he does not do so, I want to propose two "re-imaginings"; neither of which are that far removed from mainstream international law, but are nevertheless sufficiently distant from the present consensus to be worth creative consideration. The first is the work on the non-binding Maastricht Principles on the Extraterritorial Obligations of States in the Area of Economic, Social and Cultural Rights and secondly, is the work of the Independent Expert on Human Rights and International Solidarity. These are mere examples of where such normative arguments could in the future lead. ${ }^{63}$

\footnotetext{
${ }^{57}$ Salomon (2008) p. 57.

${ }^{58}$ Idem.

${ }^{59}$ CESCR (1990), para. 14.

${ }^{60}$ Alston (2005), p. 775.

${ }^{61}$ Alston (2005), p. 777.

62 de Serpa Soares (2015), p. 5.

${ }^{63}$ Note also de Serpa Soares himself who considers the institutional framework of international organisations as a key area for "growth" in international law, arguing that "international law would help to ensure that development
} 


\subsection{Maastricht Principles on the Extraterritorial Obligations of State}

The debate on respecting, protecting and fulfilling economic, social and cultural rights has been taken forward in a most interesting direction in recent years with the work of a group of experts in their personal capacity, leading to the 2011 Maastricht Principles on the Extraterritorial Obligations of States in the Area of Economic, Social and Cultural Rights. ${ }^{64}$ Such principles build on other attempts, both within the Covenant system and elsewhere, to strengthen the implementation of such rights. ${ }^{65}$ Key to the Principles is the conviction that States 'have repeatedly committed themselves to realizing the economic, social and cultural rights of everyone. This [is a] solemn commitment' ${ }^{66}$ There is insufficient space to outline in depth the Maastricht Principles in this paper, and the reader is encouraged to explore the Commentaries to the Principles. Nevertheless, certain of the fundamental propositions can be clearly outlined.

First, is the scope of jurisdiction, which is at the heart of the extraterritorial extension of duties owed to such rights. Relying on the jurisprudence of the International Court - if arguably not always directly on point - the Principles seek to demarcate the extraterritorial circumstances as to when a State may be under an obligation to secure socio-economic rights. As set down in Principle 9, quoted below:

\section{Principle 9: Scope of Jurisdiction}

A State has obligations to respect, protect and fulfil economic, social and cultural rights in any of the following:

a) situations over which it exercises authority or effective control, whether or not such control is exercised in accordance with international law;

b) situations over which State acts or omissions bring about foreseeable effects on the enjoyment of economic, social and cultural rights, whether within or outside its territory;

c) situations in which the State, acting separately or jointly, whether through its executive, legislative or judicial branches, is in a position to exercise decisive influence or to take measures to realize economic, social and cultural rights extraterritorially, in accordance with international law.

Needless to say, while the Commentaries make every effort to substantiate the existence of such bases of jurisdiction, such circumstances are not without controversy. Even circumstance (a) (where a state 'exercises authority or effective control'), though this has been the subject of significant case law in recent years, and while it can be argued convincingly that in such a situation a State has obligations to respect and protect all rights, even here, most of the case law relied on is notably in the field of civil and political rights. ${ }^{67}$

Unsurprisingly, moving onto circumstances (b) and (c), these are much more contested. For instance, circumstance (b) applies to 'situations over which State acts or omissions bring about foreseeable effects'. While the Commentaries seek to rule out any outlandlish or unworkable application of the

commitments are fulfilled by establishing institutions with mandates to assess compliance and generally-accepted set of criteria. Through such steps, international development law could move from the general and the technical to the operational - helping to fulfil the transformative development agenda' (de Serpa Soares (2015), p. 12).

${ }^{64}$ For the Principles and the Commentaries, see De Schutter, Eide, Khalfan, Orellana, Salomon, and Seiderman (2012) (hereinafter referred to as De Schutter et al.).

${ }^{65}$ For instance, the 1987 Limburg Principles on the Implementation of the International Covenant on Economic, Social and Cultural Rights (UN Doc. E/CN/4/1987/17/, Annex).

${ }^{66}$ De Schutter et al. (2012), preamble.

${ }^{67}$ For instance, the Commentaries refer to the ICJ judgments in Advisory Opinion on the Legal Consequences of the Construction of a Wall in the Occupied Palestinian Territory (2004) and Democratic Republic of the Congo v Uganda (2005), both specifically relating to the International Covenant on Civil and Political Rights. 
scope of this circumstance, noting that '[b]ecause this element of foreseeability must be present, a state will not necessarily be held liable for all the consequences that result from its conduct', ${ }^{68}$ nevertheless the Commentaries are notably lacking in state practice to justify jurisdiction in such context. Relying on dicta from international human rights courts and tribunals, it seems eminently true that there are situations in which States should - and must - promote and support the fulfilment of socio-economic rights of other populations in how they act, even where they are not in territorial or effective control. But what seems eminently true does not per se make it legally binding. One might, for instance, think of how national foreign aid programmes should be operated in a way to promote particular objectives (or, in reverse, not to apply it in a discriminatory manner); we might even argue that States have a duty of due diligence to have considered such issues in developing their programmes. But as a matter of jurisdiction, is international law sufficiently advanced to develop a proposition that the 'foreseeable effects' of such actions brings with it obligations? A legally binding good neighbour principle, as it were, writ-large?

Similarly, circumstance (c) imposes jurisdiction when a state (by itself or in concert) is 'in a position to exercise decisive influence or to take measures to realize' such rights. Again, this may seem unquestionable from a moral point of view; ${ }^{69}$ and to the extent that such obligations are tied to the general obligation on States under article 2(1) ICESCR to cooperate there is clear treaty support for it. Nevertheless 'decisive influence' as a concept here seems unduly wide in scope, building on notions on economic capacity and, what the Committee on Economic, Social and Cultural Rights, sees as those states 'which are in a position to assist others'.$^{70}$ Moreover converting soft legal aspiration (as unfortunately many States see General Comments to be) into concrete legal obligations is a significant step.

It is important to be clear what I am not saying here. I am not dismissing these Principles out-ofhand. Nor am I suggesting they may not have a significant role to play. But rather to indicate the rather paradoxical linkage - and disconnect - from present international law. With all the best putative claims to international law, there is always significant coherence between new claims and the current law. Nevertheless, notwithstanding its foundation in binding human rights law, and the Principles own claim that they clarify the content of pre-existing law rather than being progressive development ${ }^{71}$ - there is such a chasm between where States now lie and what the Principles enunciate that one but cannot consider them as de lege ferenda in many important respects, however worthy they in fact do appear.

The idea that States are under certain global responsibilities to ensure the human rights of all are protected and, in certain cases, fulfilled is not unreasonable, if however uncertain. The extraterritorial impact of policies and measures in the field of trade, investment and finance especially has long been recognised but little has been done to address the issues. ${ }^{72}$ The usual territorial limitations on jurisdiction and a general unwillingness to accept responsibility for anything other than the direct consequences for direct State action (and even then, as the jurisprudence on the jurisdictional scope of the European Convention on Human Rights has revealed, in a rather piecemeal way ${ }^{73}$ ) has left a rather substantial vacuum at the heart of human rights law.

\footnotetext{
${ }^{68}$ De Schutter et al. (2012), p. 1109.

${ }^{69}$ Cf. French (2009) 600.

${ }^{70}$ CESCR (1990), para. 14.

${ }^{71}$ Nevertheless, see the discussion on variations in State acceptance of such obligations in De Schutter et al. (2012), p. 1094.

72 See, for instance, the work of the Human Rights Independent Expert on the effects of foreign debt and other related international financial obligations of States on the full enjoyment of all human rights, particularly economic, social and cultural rights
} (http://www.ohchr.org/EN/Issues/Development/IEDebt/Pages/IEDebtIndex.aspx).

${ }^{73}$ See Milanovic (2012). 
To that extent, the Maastricht Principles - of which a few more of its key provisions are set out below as mere exemplars of the scope of this ambition - invariably push forward an ambitious agenda of international obligations for both States and other international actors; or to use Alston's phrase (though unconnected with this work) the 'internationalisation of responsibility'.

\section{Principle 20. Direct interference}

All States have the obligation to refrain from conduct which nullifies or impairs the enjoyment and exercise of economic, social and cultural rights of persons outside their territories.

\section{Principle 21. Indirect interference}

States must refrain from any conduct which:

a) impairs the ability of another State or international organization to comply with that State's or that international organization's obligations as regards economic, social and cultural rights; or

b) aids, assists, directs, controls or coerces another State or international organization to breach that State's or that international organization's obligations as regards economic, social and cultural rights, where the former States do so with knowledge of the circumstances of the act.

Of particular interest also in the Maastricht Principles is the recognition that where obligations exist, so does accountability (Principle 36) and the necessity of effective redress (Principle 37). Together, they form a set of principles which seek to take a significant stride forward in how seriously States should take their social and economic international obligations, both domestically and extraterritorially.

Nevertheless, the Maastricht Principles are, at their heart, premised on traditional conceptions of human rights - recognising the singular importance of the individual and, in some cases, the group as the rightsholder - even if their application ranges beyond the normal scope of jurisdiction ordinarily envisaged, or perhaps more accurately, accepted. As an attempt to move the debate away from the increasingly sterile conversations around third generational rights, for instance the human right to development, and towards effective implementation of what already exists, the Principles are to be considered an important step forward.

For the purposes of the Global Goals, there is of course the fundamental issue of assimilation with human rights; are the Goals to be considered sufficiently equivalent to human rights to be equally worthy of extraterritorial protection? The Commentary to the Maastricht Principles is instructive on this point, referencing together - if not invariably equating - human rights and what it views as 'multilaterally agreed goals', in this case the MDGs.

The erga omnes character of human rights may justify allowing the exercise by states of extraterritorial jurisdiction, even in conditions that might otherwise not be permissible, where such exercise seeks to promote such rights. Similarly, the realization of the MDGs is of interest to all states. Therefore, extraterritorial jurisdiction seeking to promote human rights, or the achievement of the MDGs, is not a case where one state seeks to impose its values on another state, as in other cases of extraterritorial jurisdiction. ${ }^{74}$

Critics might rightly point to a too easy conflation of treaty-based rights and political targets to make a somewhat startling claim to a settled basis of jurisdiction. ${ }^{75}$ Nevertheless, it is without question that the

\footnotetext{
${ }^{74}$ De Schutter et al. (2012), p. 1142.

${ }^{75}$ For a potentially interesting example of this already as regards the Global Goals and human rights law, see the 2016 Concluding Observations on the Committee on the Rights of the Child on the UK's fifth periodic report, in which rights under the relevant Convention and the Global Goals are grouped together. For instance, see para. 12: 'In accordance with article 4 of the Convention and Sustainable Development Goal 10, Targets 10.2 and 10.4, the Committee urges...'.
} 
domestic and regional implementation of many of the Goals will be affected by the actions of a significant number of, especially the most economically powerful and developed States. What the Maastricht Principles raise is the question of whether we should begin to attach much more directly formal responsibility and legal accountability to such actions or what Principle 9 refers to as their 'decisive influence'.

\subsection{Global Solidarity as the Unspoken Ideal in Global Development}

The second re-imagining of the Global Goals through (a particular lens of) international law is that whilst acknowledging the benefits, but also the limitations, of a traditional human rights approach to development (as ultimately the Maastricht Principles seeks to present), it is also possible to view things at an even higher (more macro-) level. Of course, this is likely to encounter much (if not more) of the same criticism, mentioned above, namely: codifying aspiration, indeterminacy and conflating political choices and normative obligations. Nevertheless, if one is to query the structure of the status quo, there is perhaps scope for deeper contestation of that which we take for granted? Of particular interest is the work of the Independent Expert on Human Rights and International Solidarity, ${ }^{76}$ who has been working on a draft declaration on this matter to be put to the General Assembly. In its most recent formulation, international solidarity is defined as follows:

International solidarity shall be understood as the convergence of interests, purposes and actions between and among peoples, individuals, States and their international organizations in order to preserve the order and ensure the very survival of international society and to achieve common goals which require international cooperation and collective action, based on the international normative system of duties which they implement and practise to foster peace and security, development and human rights.

International solidarity shall be made evident in the collective actions of States that have a positive impact on the exercise and enjoyment of human rights by peoples and individuals within and outside of their respective territories, notably in the ratification of the United Nations international human rights treaties and international labour standards and the adoption of commitments and decisions agreed upon voluntarily between and among States at the regional and international levels. ${ }^{77}$

There are, of course, some notable similarities with the work of the Maastricht Principles, especially the obligations on States to work towards the good of all 'within and outside of their respective territories'. What is perhaps different is the purpose of that cooperation; not aimed at the attainment of individual rights per se but rather 'to preserve the order and ensure the very survival of international society and to achieve common goals'. It is a view of the international community that is to some unfathomable, whereas for others it is intrinsic to the values and purposes inherent within the United Nations. It is high rhetoric, and unsurprisingly finds deep connections with much of the preambular references in Transforming Our World; ideas of co-existence, collaboration and common good. If the Maastricht Principles bends previous understandings of human rights obligations to promote new ideas of jurisdiction, responsibility and accountability, solidarity is undoubtedly more societally transformative in outlook. Whilst not undermining sovereignty - which is part of the paradox that solidarity invariably contains (how to protect and maximise domestic space whilst simultaneously seeking to achieve a common purpose?) - these ideas nevertheless reflect a fundamental challenge to the present order.

\footnotetext{
${ }^{76}$ See generally: http://www.ohchr.org/EN/Issues/Solidarity/Pages/IESolidarityIndex.aspx.

${ }^{77}$ Dandan (2014), pp. 17-18.
} 
More specifically, and for the purposes of re-imagining the normativity of the Global Goals this is vital, solidarity moves away from voluntarism towards a clearer sense of legal obligation and legal entitlement.

International solidarity is a broad principle not limited to international assistance and cooperation, aid, charity or humanitarian assistance, and that it includes sustainability in international relations, especially international economic relations, the peaceful coexistence of all members of the international community, equal partnerships and the equitable sharing of benefits and burdens. ${ }^{78}$

This is a call-to-arms to revisit structural privileges and entrenched poverty. The Draft Declaration sees as one of its fundamental principles as being 'equitable, just and fair partnerships of States as the basis of international cooperation'. ${ }^{79}$ Placing the Global Goals in the context of international solidarity, one is thus immediately struck by some of the similarity in ideas and words. This is particularly with reference to Global Goal 17, which focuses on "Partnerships for the Goals" just as the final Millennium Development Goal, MDG 8 sought to "[d]evelop a Global Partnership for Development". The targets associated with Global Goal 17 range widely but are broadly framed around finance, technology, capacity-building, and trade. Of course, international collaboration is to be found in all the Goals and not simply Global Goal 17. Particularly interesting are certain targets in Global Goal 10 ("Reducing Inequalities") and Global Goal 16 ("Peace, Justice and Strong Institutions"), which include, inter alia, targets on prioritising international aid, further implementing special and differential treatment for developing countries (particularly towards least developed countries) on matters of trade, and tackling illicit financial flows and corruption.

Nevertheless, just as with MDG 8, the new goal of partnerships struggles with various innate tensions, arguably central to its attainment. First, how to balance global governance ('enhanc[ing] global macroeconomic stability, including through policy coordination and policy coherence ${ }^{80}$ ) with sovereign discretion ('respect[ing] each country's policy space and leadership to establish and implement policies for poverty eradication and sustainable development'). Secondly, reconciling the public and regulatory objectives of Global Goal 17 with the more limited capacity of States to "nudge" the private and corporate interests behind many of these pressures. And thirdly, how to understand the role of civil society, which is both promoted within the Global Goals and is curiously muted (invariably as a response to various countries' domestic restrictive approaches to civil society involvement). It is within these tensions that the expected partnerships have already, and will continue, to operate.

But there is a more fundamental tension at play here. There would seem to be a discordance between the targets set - however worthy - and the goal itself. In short, Global Goal 17, just as with MDG 8, can be viewed as operating on two very distinct levels; with each level rhetorically, but only superficially substantively, actually connecting. On one level, are the targets set; for instance on the transfer of technology, capacity building and debt sustainability. To the extent that these undoubtedly further the Global Goals, they are instrumental in identifying and giving effect to particular means of implementation. But what they are not, and what they do not achieve, is the second level, which might be referred to, more conceptually, as a global partnership properly-conceived. Such targets, however utile, are far removed from guaranteeing what the Draft Declaration refers to as 'equitable, just and fair partnerships of States as the basis of international cooperation' - and arguably in their random selection are even some way from the slightly less aspirational title of Global Goal 17 itself. In short, the targets of Global Goal 17 have little connexion to securing the structural global change envisaged by the ambitious idealism inherent within international solidarity.

\footnotetext{
${ }^{78}$ Dandan (2014), p. 16.

${ }^{79}$ Dandan (2014), p. 18.

${ }^{80}$ Viewed as "Systemic Issues" under Global Goal 17.
} 
This is not the first attempt, of course, where claims have been made to establish a stronger legal basis for international partnership. In addition to the intergovernmental moves to establish a New International Economic Order, the International Law Association sought to promulgate legal principles which might provide a basis on which such a new understanding of international law would operate. Some of these principles included well-established rules of permanent sovereignty over natural resources and non-discrimination and other more aspirational notions of participatory equality, substantive equality and the principle of equity. ${ }^{81}$ Similar ideas are at the heart of the current work on international solidarity. As I concluded following a study of those principles, but it would seem to apply more generally to the theme of international solidarity;

A sounder argument is to consider [such] documents... as containing useful pointers - if not, in some instances, also measurable signposts - towards the achievement of longer-term goals, in this case arriving 'at a just balance between converging and diverging interests and in particular between the interests of developed and developing countries', which must be considered foundational to the functioning not only of an equitable economic system but also, in the light of changing expectations, a sustainable international community, more generally. But being longerterm makes such objectives no less important. ${ }^{82}$

Nevertheless, realism is equally important. It is important to recognise that despite international solidarity having significant moral appeal, as a legal obligation much remains uncertain. Scobbie is particularly insightful when he notes: 'Can a sufficient solidarity easily be assumed, or would the rejection of a Vattelian world-view risk the emergence of a (greater) world-anarchy? Even within territorial units, would social cohesion be maintained?'. ${ }^{83}$ Even if one were not to envisage crisis rather than harmony as the consequence of solidarity, progressive movement towards the goal requires confronting a conundrum as yet unresolved in international polity; 'whatever autonomous normative authority (be it even of a rhetorical kind) one may believe international law to possess - it does not yet have a mandate to coerce states to accept that to which they do not voluntarily subscribe' ${ }^{84}$

\section{Conclusion}

The Global Goals would seem to be a momentous achievement for the international community. First, they are an endorsement of an approach to development that the UN has finally found some global traction - with member states, partner institutions and socially aware private enterprise, building on the overall, though by no means absolute, success of the MDGs. Secondly, the Global Goals themselves are notable in several key respects; in their creation, in their scope and in their scale of ambition. The UN has an aspirational agenda of huge proportions over the next fifteen years; and, as noted above, unlike some of the MDGs which were achieved by proxy via improvements in GDP, most of the Global Goals are linked to more nuanced changes in policy, institutional structures and consumer and industrial behaviour. There are arguably fewer "quick fixes" in the Global Goals.

For the international lawyer, however, the Global Goals present something of a conundrum. They are not legally binding, nor are they written in legal text. They may, of course, involve changes, or require the implementation, of the law. But equally they may not. As noted above, law is often regarded as a fact - a fixed framework - through which the Goals must work; occasionally it might also be viewed as a useful tool. But in both cases, law is perceived in instrumental terms and for particular purposes.

\footnotetext{
${ }^{81}$ ILA (1986), pp.1-11.

${ }^{82}$ French (2008), p. 32, quoting ILA (1986), p. 5.

${ }^{83}$ Scobbie (2005), p.312.

${ }^{84}$ French (2012), p. 701.
} 
For those who want to envisage the Global Goals as having greater normative force in international law, the scope for discourse seems much more limited.

Of course, the clearest way to view the Global Goals as international law would be to argue that they have, or are working towards, customary status. Certainly, arguments of a similar kind were made towards the MDGs. Regardless of whether that was true of the previous goals, I am simply unconvinced that this is possible for many of the Global Goals. Setting aside, at present, how far States will actively and consistently work towards making such Goals a reality (the "State practice"), I have little sense that one would be able to deduce acceptance from what States do or how they discuss the Goals (the "opinio juris"). For me, looking for customary status is an interesting endeavour, but unlikely to be productive. Moreover, Global Goals are not like those general principles of international law or norms of jus cogens, which are invariably upheld in treaties, official documentation and speeches, and thus is said to compensate for variable State practice. The prohibition on torture, for instance. Global Goals are overtly, and remain, in the political sphere.

And for me, this also prevents an argument that such Goals are emerging as soft law. For proponents, soft law may appear a rather neat way to tackle the lack of present bindingness in the Global Goals, while still wanting to give them normative credence. But as I discuss, what makes soft law from a legal perspective is not per se the fact that it is official yet not binding, but that there is paradoxically an intention to regulate in the absence of law. Moreover, much soft law is on a journey to some form of "hardness"; it is invariably this transitional stage which makes soft law usable from a lawyer's perspective. In respect of both of these criteria, the Global Goals fall down. They are neither designed to be regulatory nor is it particularly apparent that they are progressing towards bindingness. Thus, the question becomes what relevance the nomenclature of soft law, other than a neat (if unhelpfully generalised) categorisation?

This leaves open a range of possibilities; to abandon law or to embrace alternatives. Above, the paper poses two re-imaginings - both putative in nature; developing the extraterritorial extent of the present law and, more radically, embracing a normative approach to international solidarity. As identified, neither are susceptible to providing easy solutions to global problems. Not only because they raise questions of positive law - which is surely inherent in the nature of a re-imagining - but also because they can be questioned as to how practicable they might turn out to be. For developed States, in particular, where voluntarism determines much development activity, it is extremely unlikely that either more expansive interpretations of pre-existing obligations (Maastricht Principles) or a more holistic account of global partnership (international solidarity) will find favour. Nevertheless, what both do - in their own way - is to force us to question the relevance of international law in the pursuit of development. Why is international law not viewed as an acceptable conduit and process for advancement of global development? International lawyers are still some way off from formulating and persuading others of - a convincing response to this question; and perhaps we need to do this before we enter into our own (often internal and self-referential) dialogues of which of the differing "routes" to legality are found to be the more persuasive.

But in being cautious moving forward, let us not reject such re-imaginings as the stuff of childish things. As Allott has so forcefully argued:

we found within ourselves another capacity, the capacity to form the idea of the ideal — the idea of a better human future which we can choose to make actual...To overcome the tyranny of the actual, to overcome the ignorant and infantile belief that the actual self-organising of humanity is necessary and inevitable, we need only recall and recover our extraordinary power constantly to re-conceive the ideal, in order yet again to choose to make it actual. ${ }^{85}$

${ }^{85}$ Allott (1999) p. 50. 
Author Bio: Professor Duncan French is Head of School and Professor of International Law, University of Lincoln, United Kingdom.

\section{Acknowledgments}

Can I thank the editors of the Yearbook, the anonymous reviewers and Dr. Graham Melling for the insightful observations on a draft of this paper.

\section{Bibliography}

Allott P (1999) The Concept of International Law. European Journal of International Law 10:31-50

Alston P (2005) Ships Passing in the Night: The Current State of the Human Rights and Development Debate seen through the Lens of the Millennium Development Goals. Human Rights Quarterly 27:755829

Alston P (2015) Report of the Special Rapporteur on extreme poverty and human rights (4 August 2015) UN Doc. A/70/274

Amin S (2006) The Millennium Development Goals: A Critique from the South. Monthly Review 57 http://monthlyreview.org/2006/03/01/the-millennium-development-goals-a-critique-from-the-south/

Boas M and McNeill D (eds) (2003) Global Institutions and Development: Framing the World? Routledge, London

Boyle A and Chinkin C (2007) The Making of International Law. Oxford University Press, Oxford

CESCR (1990) General Comment 3 ('The Nature of States Parties Obligations (Art. 2 par. 1)') (14 December 1990) UN Doc. E/1991/23

Committee on the Rights of the Child (2016) Concluding Observations on the Fifth Period Report of the United Kingdom of Great Britain and Northern Ireland (3 June 2016) UN CRC/C/GBR/CO/5.

Dandan V (2014) Report of the Independent Expert on human rights and international solidarity (1 April 2014) UN Doc. A/HRC/26/34

Darrow M (2003) Between Light and Shadow: The World Bank, The International Monetary Fund and International Human Rights Law. Hart, Oxford

De Schutter O, Eide A, Khalfan A, Orellana M, Salomon M, and Seiderman I (2012) Commentary to the Maastricht Principles on Extraterritorial Obligations of States in the Area of Economic, Social and Cultural Rights. Human Rights Quarterly 34:1084-1169

De Serpa Soares M (2015) Room for Growth: The Contribution of International Law to Development. Chinese Journal of International Law 14:1-13

French D (2008) 'From Seoul with love': the continuing relevance of the 1986 Seoul ILA declaration on progressive development of public international law relating to a new international economic order. Netherlands International Law Review 55:3-32

French D (2009) Global Justice and the (Ir)relevance of Indeterminacy. Chinese Journal of International Law 8:593-619 
French D (2012) International Development Law in the Spirit of Solidarity: A Personal View on the "International Law of the Ordinary". In Morin M, Cordonier Segger M-C, Gélinas F, and Gehring M (eds) Responsibility, Fraternity and Sustainability in International Law. LexisNexis, Ontario, p.687-701

French D (2015) Editorial: The 2015 Global Goals: the (Present) World is Not Enough. Environmental Liability 23: 77-79

Green M (2015) Just Getting Richer is not going to get us to the Global Goals http://www.theguardian.com/global-development-professionals-network/2015/oct/08/just-gettingricher-is-not-going-to-get-us-to-the-global-goals-economic-growth

Hickel J (2015) The Problem with Saving the World https://www.jacobinmag.com/2015/08/globalpoverty-climate-change-sdgs/

ILA (1986) Declaration on the Progressive Development of Principles of Public International Law relating to a New International Economic Order. International Law Association (ILA), London

IMF (2014) Strengthening the Contractual Framework to Address Collective Action Problems in Sovereign Debt Restructuring (http://www.imf.org/external/np/pp/eng/2014/090214.pdf)

Meagher R (1979) International Redistribution of Wealth and Power: A Study of the Charter of Economic Rights and Duties of States. Pergamon Press, New York

Milanovic M (2012) Al-Skeini and Al-Jedda in Strasbourg. European Journal of International Law 23:121-139

Millennium Development Goals Indicators, http://unstats.un.org/unsd/mdg/Host.aspx?Content=Indicators/About.htm

Ruggie J (2006) Interim Report of the Special Representative of the Secretary-General on the Issue of Human Rights and Transnational Corporations and Other Business Enterprises (UN Doc. E/CN.4/2006/97)

Rühmkorf A (2015) Corporate Social Responsibility, Private Law and Global Supply Chains. Edward Elgar, Cheltenham

Salomon M (2007) Global Responsibility for Human Rights: World Poverty and the Development of International Law. Oxford University Press, Oxford

Salomon M (2008) Poverty, Privilege and International Law: The Millennium Development Goals and the Guise of Humanitarianism. German Yearbook of International Law 51: 39-74

Scobbie I (2005) Slouching towards the Holy City: Some Weeds for Philip Allott. European Journal of International Law 16:299-313

UN (2011) Guiding Principles on Business and Human Rights: Implementing the United Nations "Protect, Respect and Remedy" Framework (UN Human Rights Office of Human Rights Commissioner) UN Doc. A/HRC/17/31 (endorsed by the Human Rights Council in HRC resolution 17/4 (16 June 2011))

UN (2015) Addis Ababa Action Agenda of the Third International Conference on Financing for Development

(https://sustainabledevelopment.un.org/index.php?page=view\&type=400\&nr=2051\&menu=35)

UNDP (1994) Human Development Report: New Dimensions of Human Security (http://hdr.undp.org/en/content/human-development-report-1994) 
UNGA (2015) Transforming Our World: the 2030 Agenda for Sustainable Development (21 October 2015) UN Doc. A/RES/70/1

Various (2011) Five Decades of Development Debate on Sustainability. Development 54: 271-281

Vogelstein R (2015) Gender Equality and the Global Goals (http://blogs.cfr.org/women-around-theworld/2015/10/06/gender-equality-and-the-global-goals/)

Wendt N (1999) 50th Anniversary of the World Bank and the IMF prompts Criticisms. Transnational Law and Contemporary Problems 9:149-162

World Commission on Environment and Development (1987) Our Common Future. Oxford University Press, Oxford

WTO (2015) Nairobi $\quad$ Ministerial Declaration

(https://www.wto.org/english/thewto_e/minist_e/mc10_e/mindecision_e.htm) 